\title{
LIN-12/Notch signaling lessons from worms and flies
}

\section{Iva Grenwal d'}

Department of Biochemistry and Molecular Biophysics, Howard Hughes M edical Institute, Columbia University College of Physicians and Surgeons, N ew York, N ew York 10032 USA

LIN-12/N otch proteins function as receptors for intercellular signals during development. Many aspects of LIN-12/ N otch-mediated signaling have been elucidated through studies of cell-cell interactions that occur during Caenorhabditis elegans and Drosophila melanogaster development. The basic principles that operate in these lower organisms have al so been shown to apply to vertebrates (for review, see Gridl ey 1997). M olecular features defined in lower organisms have also been shown to be conserved in vertebrates, including components of the signaling and signal transduction systems (for review, see Weinmaster 1997). Thefocus of this paper is on what has been learned about LIN-12/N otch signaling from invertebrates. First, a description of roles for LIN $12 / \mathrm{N}$ otch proteins in development is given, using different model cell fate decisions to illustrate various features. A discussion of the mechanism of LIN-12/N otch signal transduction follows, including new in vivo evidence that favors the direct participation of the intracelIular domain of LIN -12/N otch proteins in regulating target gene expression. Finally, other influences on LIN -12/ Notch activity are discussed, particularly protein turnover and protein processing.

\section{The LIN-12/Notch "pathway"}

Genetic studies have identified many conserved components that are important for LIN-12/N otch signaling. Table 1 summarizes the $C$. el egans and D rosophila genes involved in LIN-12/N otch signaling mentioned here, and their vertebrate counterparts. Of particular note is that transmembrane protein ligands of the conserved Delta/Serrate/LAG-2 (DSL) family activate LIN-12/ $\mathrm{N}$ otch signal transduction (for review, see Weinmaster 1997) and that many LIN-12/N otch outputs are mediated by a transcription factor named Suppressor of Hairless [Su(H)] in Drosophila and LAG-1 in C. elegans (see Schweisguth and Posakony 1994; Bailey and Posakony 1995; LeCourtois and Schweisguth 1995; Christensen et al. 1996). One "pathway" involving Su(H) is considered below and is diagrammed in Figure 2 (below). However, there is evidence that certain responses to activated

1E-MAIL greenwald@cuccfa.ccc.columbia.edu; FAX (212) 305-1721.
N otch do not depend on Su(H) (Lecourtois and Schweisguth 1995; Shawber et al. 1996; Wang et al. 1997) and, as described below, there are other potential roles for LIN $12 / \mathrm{N}$ otch proteins that may use other signal transduction components.

\section{LIN-12/Notch proteins mediate cell-cell interactions}

The fundamental role inferred from genetic studies of LIN -12/N otch proteins is that they mediate inductive or lateral cell-cell interactions that specify cell fate. Inductive interactions involve signaling between nonequivalent cells. There are numerous examples of inductive interactions mediated by LIN-12/N otch proteins, and in many of these cases, the expression of ligand in the inducing cell or tissue appears to be the critical regulatory step. For example, two inductive interactions mediated by the $C$. elegans LIN-12/N otch protein GLP-1 have been studied in some detail. GLP-1 is expressed during embryogenesis by two equivalent blastomeres, $A B a$ and ABp (Crittenden et al. 1994); the ligand APX-1 is expressed by a nonequivalent blastomere, $\mathrm{P}_{2}$, and induces $A B p$ to follow a distinct fate from $A B a$ (Mango et al. 1994; Mello et al. 1994; M ickey et al . 1996). GLP-1 is al so expressed in the germ line; the ligand LAG-2 produced by a somatic gonadal cell activates GLP-1 in the germ line to promote mitosis (Crittenden et al. 1994; Henderson et al. 1994).

Lateral interactions occur within a population of equival ent cells and result in the generation of cells of different types. This process has been termed "lateral inhibition," because it has been envisaged as a competition between cells for one of the fates, with one cell deciding to adopt a default fate (the fate it would adopt if it were isolated from the other cells) and then inhibiting others from adopting that fate (Wigglesworth 1940; Lawrence 1992). However, results from genetic studies of Iin-12 in C. elegans and N otch in Drosophila suggest that cells communicate with each other prior to commitment to either fate, so that the cells essentially specify each other; hence, I prefer the term "Iateral specification" for this process. In some cases, other factors influence the outcomes of signaling between cells that are essentially equivalent. 
Table 1. C. el egans and Drosophila genes featured

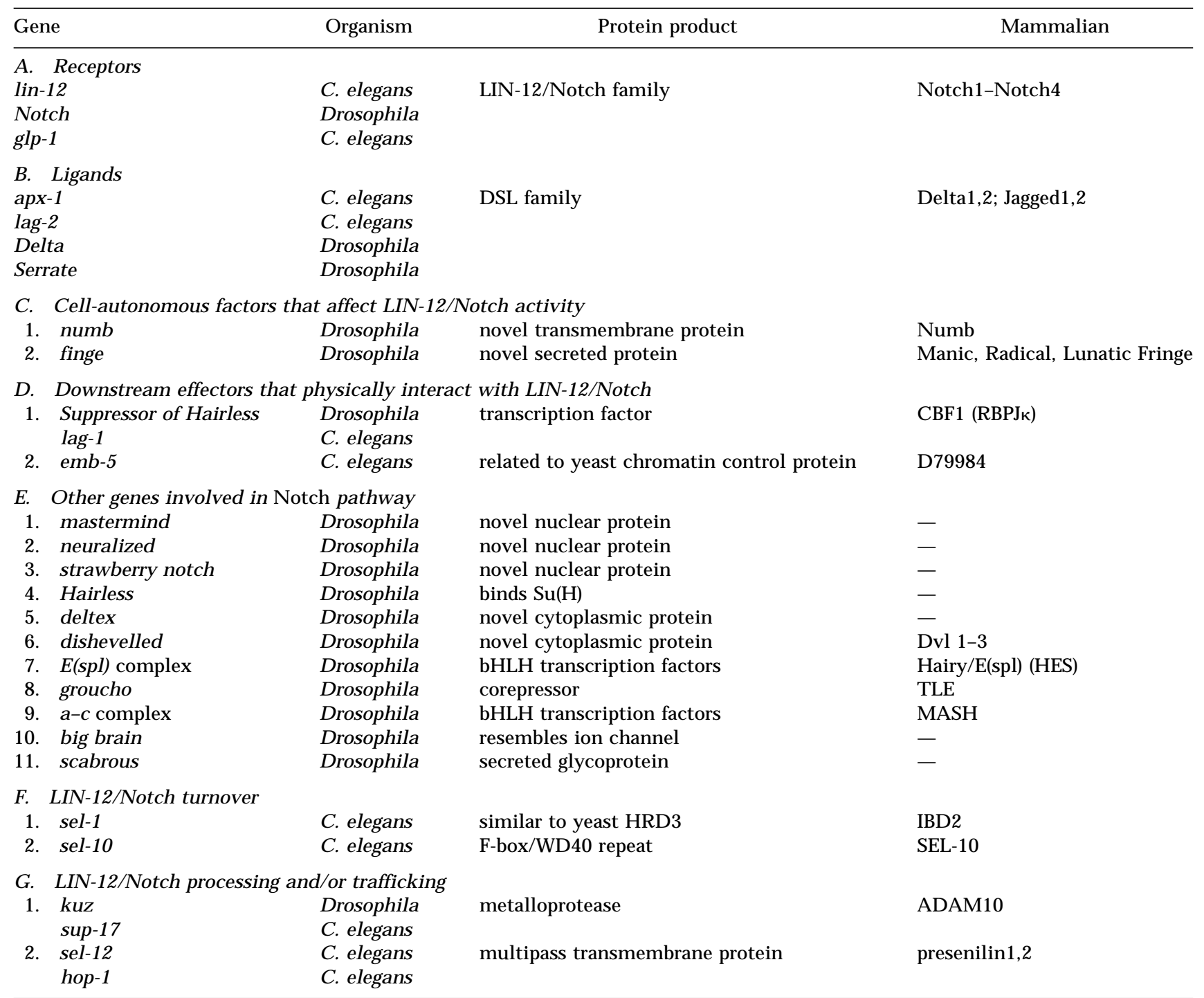

See text for details and references concerning C. el egans and Drosophila proteins. References for mammalian homologs are given in Weinmaster (1997), except for mammalian Fringe proteins (Johnston et al. 1997), IBD2 (I. Biunno, pers. comm.), SEL-10 (G. Wu and J. Kitajewski, pers. comm.), and ADAM 10 (Wolfsberg and White 1996).

\section{Feedback mechanisms during lateral specification}

In the absence of other influences, Iateral specification is stochastic, in that any cell in the population could adopt the default fate. Studies of lin-12/Notch activity in C. el egans and Drosophila have suggested that during some cell fate decisions, differences in lin-12/Notch activity are amplified by feedback mechanisms that affect both ligand and receptor expression. These principles are exemplified by a simple decision involving only two equival ent cells in $\mathrm{C}$. el egans gonadogenesis and a decision involving a small group of equivalent cells in Drosophila sense organ devel opment.

The first evidence that LIN-12/N otch-mediated lateral specification involves the amplification of a stochastic small difference between equival ent cells came from a study of LIN-12-mediated signaling between two cells of the hermaphrodite gonad of $C$. elegans (see Fig. 1 ). These gonadal cells, named Z1.ppp and Z4.aaa, are initially equivalent in their developmental potential in that each has an equal chance of becoming the anchor cell (AC), a terminally differentiated cell type, or a ventral uterine precursor cell (VU), which contributes descendants to the ventral uterus (Kimble and Hirsh 1979). However, in any given hermaphrodite, only one of these cells will become the AC, whereas the other becomes a $\mathrm{VU}$, depending on interactions between them (Kimble 1981; Seydoux and Greenwald 1989).

The interactions between Z1.ppp and Z4.aaa are me di ated by lin-12 and lag-2, a gene encoding a DSL ligand (Greenwald et al. 1983; Lambie and Kimble 1991; Henderson et al. 1994; Tax et al. 1994). Mutations that constitutively activate lin-12 have no AC, and mutations that eliminate lin-12 activity have two ACs 

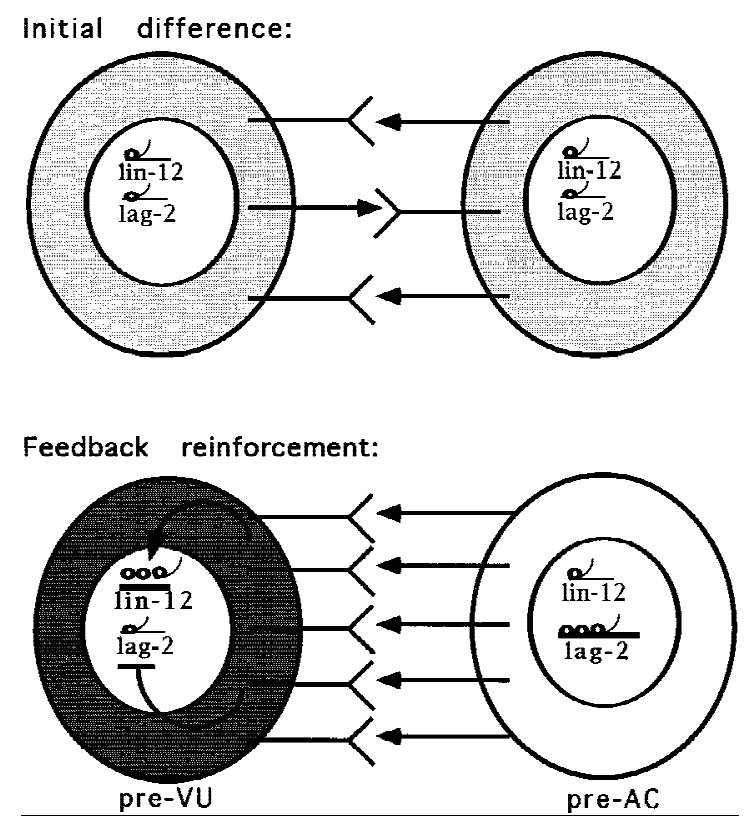

Figure 1. A feedback mechanism during the $C$. elegans $A C /$ $\mathrm{VU}$ decision. The AC/VU decision is a simple example of lateral specification involving only two equivalent cells. These two cells interact with each other so that one becomes the AC and the other becomes a VU. A stochastic small difference in ligand or receptor activity (top) is amplified by a feedback mechanism (bottom) that involves differential transcription of genes encoding the ligand (lag-2) and receptor (lin-12). This same basic mechanism appears to operate during certain other LIN-12/N otch-mediated decisions, including Drosophila SOP specification.

(Greenwald et al. 1983). Thus, activation of lin-12 results in the VU fate; failure to activatelin-12 results in the AC fate.

Genetic mosaics in which lin-12(+) and lin-12(0) cells are juxtaposed suggested the existence of a feedback mechanism (Seydoux and Greenwald 1989). In genetic mosaics in which either Z1.ppp or Z4.aaa lacked lin-12 activity [lin-12(0)] while the other cell was lin-12(+), the lin-12(0) cell al ways became an AC, presumably because it could no longer receive the signal. In addition, the lin-12(+) cell al ways became a VU and therefore behaved differently in the genetic mosaic than in wild type, where it has an equal chance of becoming an AC. These observations suggested that a stochastic variation in Iigand and/ or receptor activity between Z1.ppp and Z4.aaa is amplified by a feedback mechanism in both cells.

A nalysis of the patterns of lin-12 and lag-2 expression during the $\mathrm{AC} / \mathrm{VU}$ decision suggested that transcriptional control is a component of the feedback mechanism (Wilkinson et al. 1994). Initially, lin-12 and lag-2 are expressed in both Z1.ppp and Z4.aaa. However, the expression patterns change in a reciprocal manner, so that lin-12 expression becomes restricted to the presumptive VU and lag-2 expression becomes restricted to the presumptive AC. These changes in gene expression occur prior to commitment. Furthermore, they are influ- enced by lin-12 activity, which appears to promote expression of Iin-12 and to repress expression of lag-2. If the later phase of lin-12 expression in the presumptive VU is reduced by deleting a $5^{\prime}$ regulatory element, a VU is not made, indicating that positive autoregulation of lin-12 transcription in the presumptive $\mathrm{VU}$ is necessary to specify the $\mathrm{VU}$ fate.

Studies in Drosophila have suggested that such feedback mechanisms operate in other cell fate decisions (Heitzler and Simpson 1991; see also Huppert et al. 1997), as exemplified by specification of sensory organ precursors (SOPs) that give rise to bristles on the notum. During development of the peripheral nervous system, equival ent proneural cells within a small cluster interact via N otch so that one becomes the SOP, giving rise to a neuron and accessory cells, whereas the others become epidermis (Stern 1954; Shellenbarger and Mohler 1978; Hartenstein and Posakony 1990; Simpson 1990).

A feedback mechanism was again inferred by the observation of a bias in cell fate choice in genetic mosai cs: When $\mathrm{Notch}^{+}$cells are juxtaposed to $\mathrm{Notch}^{-}$cells, the Notch ${ }^{-}$cells al ways become SOPs and the Notch ${ }^{+}$cells always become epidermis (Heitzler and Simpson 1991). Furthermore, the opposite bias in cell fate choice was observed in genetic mosaics involving the ligand Delta: When Delta $^{+}$cells are juxtaposed to Delta ${ }^{-}$cells, the Delta ${ }^{-}$cells become epidermis and the Delta ${ }^{+}$cells become SOPs (Heitzler and Simpson 1991). Support for the involvement of transcriptional control in this feedback mechanism during SOP specification has been suggested by analysis of genetic mosaics involving genes of the achaete-scute (ac-sc) complex (Heitzler et al. 1996), known transcriptional activators of Delta (Kunisch et al. 1994), and the analysis of the pattern of Del ta expression in the SOP lineage (Parks et al. 1997).

In Drosophila, the downstream effects of activating $\mathrm{N}$ otch have been intensively studied. Although the circuitry underlying Notch positive autoregulation is not known, the circuitry underlying the feedback loop that represses ligand expression upon receptor activation during SOP specification has been well described (Fig. 2; Heitzler et al. 1996). Su(H) is the key effector upon $\mathrm{N}$ otch activation in SOP specification (Schweisguth and Posakony 1994; Bailey and Posakony 1995; Lecourtois and Schweisguth 1995; Schweisguth 1995). Su(H) promotes expression of genes of the Enhancer of split [E(spl)] complex encoding basic hel ix-loop-helix (bHLH) proteins (Bailey and Posakony 1995; Lecourtois and Schweisguth 1995), which combine with a protein called Groucho (which maps to the E(spl) complex but is not a bHLH protein) to create a repressor (Paroush et al. 1994; Fisher et al. 1996). The E(spl) bHLH-Groucho protein complex represses genes of the ac-sc complex, which encodes multiple proteins of a different bHLH class (Oellers et al. 1994; Heitzler et al. 1996). As the Ac-Sc proteins activate expression of Delta (Kunisch et al. 1994), this feedback loop operates to repress Delta expression in the cell in which Notch has been activated.

There are two additional points pertaining to SOP specification that should be noted here. First, the ac-sc 


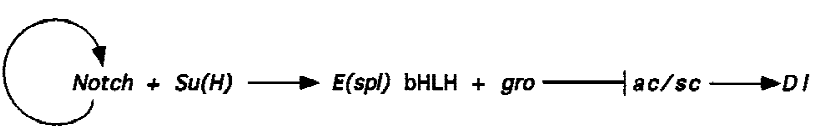

Figure 2. A genetic pathway for the repression of Delta expression in response to $\mathrm{N}$ otch activation during SOP specification. (Arrow) A positive interaction; (blunted arrow) a negative interaction; (circular arrow) positive autoregulation.

genes also act upstream of Notch, in that expression of ac-sc complex genes establish the proneural clusters. Global positional cues govern the pattern of ac-sc expression to establish the proneural clusters that undergo Notch-mediated cell-cell interactions (for review, see Skeath and Carroll 1994). The Notch-mediated interactions lead to increased expression of ac-sc in the presumptive SOP and repression of ac-sc in other cells of the cluster. Second, for certain macrochaetes (large bristles) the position of the SOP is not always in the center of the cluster; however, the SOP is generated at a reproducible position within a cluster (Cubas et al. 1991), suggesting that other factors may influence the specification of the SOP.

\section{Biased LIN-12/Notch-mediated interactions}

LIN-12/N otch proteins are also involved in specifying the fates of cells in invariant lineages. In these cases, although each cell of an equivalence group has the potential to adopt either the default or the al ternative fate, intrinsic or extrinsic factors lead to a predictable outcome.

\section{Asymmetric segregation of modulating factors:} Drosophila Numb

A notable example of a lineage-based mechanism that bi ases a N otch-mediated interaction occurs during Drosophila SOP devel opment, where the asymmetric segregation of $\mathrm{N}$ umb modulates $\mathrm{N}$ otch activity in one of two daughter cells (Fig. 3). The SOP normally undergoes a defined lineage, producing two daughters: One daughter produces a hair cell and a socket cell; the other daughter produces a neuron and a sheath cell (Hartenstein and Posakony 1989). Temperature-shift experiments have established that Notch and Delta function at each step of the lineage (Hartenstein and Posakony 1990; Parks and Muskavitch 1993): If Notch activity is reduced around the time of the first SOP division, the two daughters each produce a neuron and a sheath cell; if Notch activity is reduced at both the first and second divisions in the SOP lineage, four neurons are generated. The involvement of Notch and Delta at these steps of the SOP lineage imply that cell-cell interactions between the SOP daughters and between SOP granddaughters are important for generating differences within the SOP lineage.

numb was identified by its effects on $\mathrm{N}$ otch-mediated cell fate decisions (U emura et al . 1989). numb appears to have a cell-intrinsic influence on $\mathrm{N}$ otch-mediated sig- naling in several lineages. For example, at each successive step in the SOP lineage, the Numb protein is be lieved to be newly synthesized and then preferentially segregated into one of the SOP daughters (Rhyu et al. 1994; Knoblich et al. 1995) (see Fig. 3). Jan and Jan (1995) have suggested that numb influences $\mathrm{N}$ otch-mediated signaling at successive steps in the SOP lineage by reducing Notch activity in the cell that contains Numb, thereby biasing the interaction between sister cells that signal each other. They envisage the numb-imposed bias as a mechanism to increase the reliability of $\mathrm{N}$ otch-mediated signaling in situations requiring rapid decision making, when there may be insufficient time to activate transcription-based feedback mechanisms (Jan and Jan 1995).

The asymmetric localization of $\mathrm{N}$ umb also has been shown to influence a $\mathrm{N}$ otch-mediated inductive interaction in a central nervous system (CN S) lineage. Two sister cells, dMP2 and VMP2, adopt different fates during CN S development as a result of an inductive signal emanating from outside the MP2 lineage (Spana and Doe 1996). The preferential segregation of Numb into the dM P2 cell appears to account for the different response of the sister cells to the inductive signal (Spana and Doe 1995, 1996; Spana et al. 1995).

$\mathrm{Numb}$ is a novel membrane-associated protein (Uemura et al. 1989). The amino-terminal portion of $\mathrm{N} \mathrm{umb}$ appears to interact physically with the amino-terminal portion of the Notch intracellular domain (Guo et al. 1996). The mechanism by which Numb binding to $\mathrm{N}$ otch inhibits $\mathrm{N}$ otch activity is not known; one possibility is that Numb interferes with the interaction of $\mathrm{N}$ otch with $\mathrm{Su}(\mathrm{H})$ or another transcription factor.

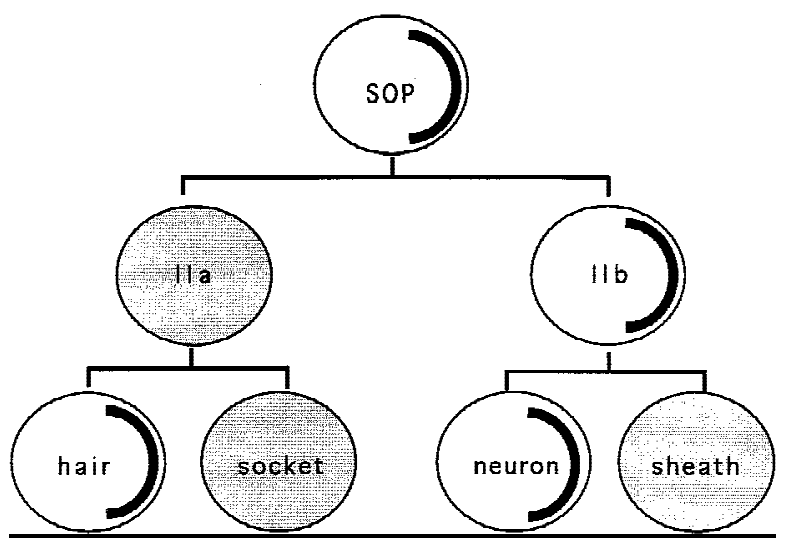

Figure 3. Modulation of Notch activity by numb in the SOP lineage. The SOP undergoes a defined cell lineage, and the activity of Notch and numb is involved at each step. At each division, asymmetric segregation of $\mathrm{N} \mathrm{umb}$ (dark crescent) reduces $\mathrm{N}$ otch activity in the cell that receives it, so that the cell lacking numb activity adopts the fate associated with activated Notch (shaded circles). If Notch activity is absent or if numb activity is provided to all SOP descendants by overexpression, four neurons are generated; if numb activity is absent or if Notch activity is provided to all SOP descendants by overexpression, four socket cells are generated. 
Differential expression of modulating factors: Drosophila Fringe

Studies of the Drosophila fringe gene suggest that Fringe influences the response of cells to ligands for $\mathrm{N}$ otch (Irvine and Wieschaus 1994; Kim et al. 1995; Fleming et al. 1997; Panin et al. 1997; for review, see Irvine and Vogt 1997) (see Fig. 4). The rol e of Fringe is best understood in the induction of the Drosophila wing margin. The dorsal and ventral compartments of the wing primordium are destined to form the dorsal and ventral surfaces of the wing blade. The wing margin forms where these two compartments meet; both dorsal and ventral cells at the interface become specialized margin cells. The wing margin cells secrete a morphogen that organizes wing development and also specifies the distinctive structures of the wing margin, including a highly stereotyped pattern of mechanosensory bristles (for review, see Lawrence and Struhl 1996). N otch-mediated interactions between dorsal and ventral cells establish the wing margin via a complex interplay of regulatory interactions among $\mathrm{N}$ otch and Fringe, and the N otch ligands Delta and Serrate.

The role of fringe appears to be to cause $\mathrm{N}$ otch to respond to Delta rather than Serrate. Serrate has been implicated as a signal from dorsal to ventral cells (DiazBenjumea and Cohen 1995; Kim et al. 1995; DeCelis et al. 1996), whereas Del ta has been implicated as a signal from ventral to dorsal cells (Diaz-Benjumea and Cohen 1995; DeC elis et al. 1996; Doherty et al. 1996). The patterns of Delta and Serrate expression change over time, dependent on $\mathrm{N}$ otch activity. Early in wing develop-

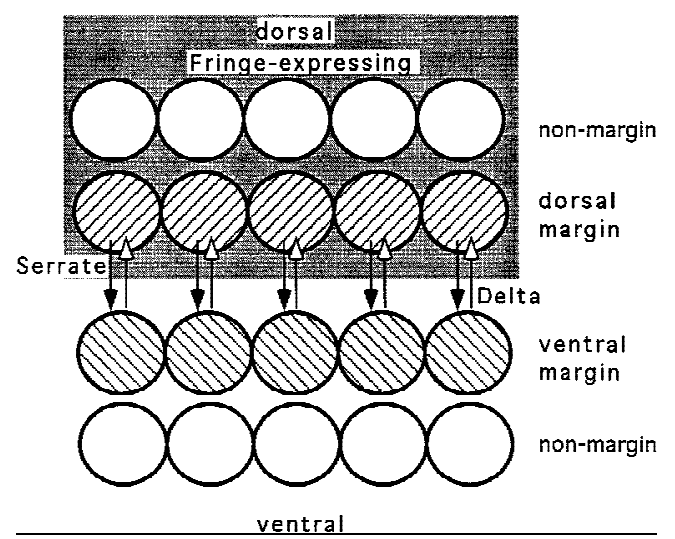

Figure 4. The modulation of Notch activity by fringe during Drosophila wing margin specification. The wing margin forms where the dorsal and ventral compartments are juxtaposed. Formation of the wing margin requires the activity of the Notch (receptor), Delta (ligand), and Serrate (ligand) genes, and the activity of fringe (modulator). Activation of N otch at the boundary between the dorsal and ventral compartments specifies cells on either side of the boundary as the wing margin. The dorsally restricted expression of Fringe is important for limiting the induction of N otch by Serrate and Delta to thin stripes of dorsal and ventral cells that interact across the dorsoventral compartment boundary. (Solid arrow) Serrate; (open arrow) Delta; (hatched cells) $\mathrm{N}$ otch is activated. ment, Serrate and Fringe are expressed in all cells of the dorsal compartment under the control of the dorsal selector gene apterous, whereas Delta is expressed in all cells of both the dorsal and ventral compartments. However, Delta expression is dramatically up-regulated in ventral cells along the boundary, in response to Serrate expressed by dorsal cells. Conversely, high levels of Delta induced by Serrate in ventral cells signal back across the boundary and up-regulate Serrate expression in dorsal cells. The end result is a localized activation of $\mathrm{N}$ otch in adjacent stripes of cells that abut at the dorsal / ventral compartment boundary, specifying these cells to become wing margin cells.

The presence or absence of Fringe appears to determine to which $\mathrm{N}$ otch ligand wing cells respond. Thus, ventral cells (which normally lack Fringe) are primed to respond to Serrate (expressed by dorsal cells). Conversely, wing cells that express Fringe are refractory to Serrate but primed to respond to Delta (expressed at high levels in ventral cells in response to Serrate). As argued by Panin et al. (1997), the dorsally restricted expression of Fringe is therefore responsible for limiting the induction of $\mathrm{N}$ otch by Serrate and Delta to thin stripes of dorsal and ventral cells that interact across the dorsoventral compartment boundary. This Fringe-dependent bi as is reinforced by an unexpected property of Delta and Serrate signaling in the wing disc: for unknown reasons, cells that express high levels of Delta or Serrate themselves appear unable to receive the same ligand they express and, hence, are further biased to receive the other ligand (see al so Micchelli et al. 1997). Panin et al. (1997) point out that this seemingly complicated mechanism may be used to ensure the correct placement of a source of morphogen to pattern a symmetrical structure.

fringe encodes a novel protein that is predicted to be secreted but acts cell-autonomously (Irvine and Wieschaus 1994; Panin et al. 1997). It will be of interest to learn if Fringe modifies the interaction of $\mathrm{N}$ otch with its ligands or the response of $\mathrm{N}$ otch upon the binding of a subset of ligands.

Cell signaling: C. elegans vulval precursor cell fate patterning

The patterning of fates of the vulval precursor cells (VPCs) in C. elegans (for review, see Greenwald 1997; Kornfeld 1997) may exemplify the use of a heterol ogous cell signaling mechanism to superimpose a bias on a LIN -12/N otch-mediated process (Fig. 5). In wild-type hermaphrodites, three hypodermal cells, P5.p, P6.p, and P7.p, are VPCs and generate the cells that form the vulva. These cells lie under the somatic gonad, with P6.p centered under the anchor cell. Although P5.p, P6.p, and P7.p all have similar developmental potential, they always adopt a pattern of fates that may be represented as $2^{\circ}-1^{\circ}-2^{\circ}$ (Sul ston and White 1980; Sternberg and Horvitz 1986). This pattern primarily reflects the activity of two different signaling pathways. One pathway involves an inductive signal from the anchor cell that is transduced 
by the LET-23 receptor tyrosine kinase in the vulval precursor cells (for review, see Kornfel d 1997). It is not clear whether the inductive signal is spatial ly graded (see Katz et al. 1995) or restricted so that only P6.p is induced (see Koga and Ohshima 1995; Simske and Kim 1995). The other pathway involves a LIN -12-mediated lateral signal thought to occur between neighboring vulval precursor cells (Sternberg 1988).

lin-12 transcription appears to remain uniform during VPC specification, suggesting that a transcription-based feedback mechanism analogous to that used in the AC/ $\mathrm{VU}$ decision is not used to establish the pattern of vulval fates (Wilkinson and Greenwald 1995). Instead, reception of the inductive signal appears to be an important influence on lateral signaling: In let-23 genetic mosaics, a let-23(-) VPC adopts the $2^{\circ}$ fate when adjacent to a let-23(+) VPC (Koga and Ohshima 1995; Si mske and Kim 1995). This observation suggests that inductive signaling (whether spatially graded or not) appears likely to govern the expression or activity of the ligand for LIN-12. Furthermore, inductive signaling appears to cause a specific down-regulation of LIN-12 protein accumulation (D. Levitan and I. Greenwald, unpubl.). Thus, a combi nation of ligand up-regulation (transcriptional or post-transcriptional) and receptor down-regulation (post-transcriptional) may bias P6.p to adopt the $1^{\circ}$ fate.

It is interesting to note that reduction in the activity of rhomboid, which potentiates the activity of the Drosophila EGF receptor, causes reduced expression of Del ta during wing vein development (Sturtevant et al. 1993). This appears to be another example of a linkage of EGF receptor activity to DSL ligand expression, al though the effect of EGF receptor activity in this case is the opposite effect of what appears to occur during $C$. elegans VPC specification.

\section{Other developmental roles for LIN-12/Notch proteins}

Most work on LIN-12/N otch proteins has been concerned with their roles in mediating cell fate decisions. However, in Drosophila, Notch and its Iigand Del ta have

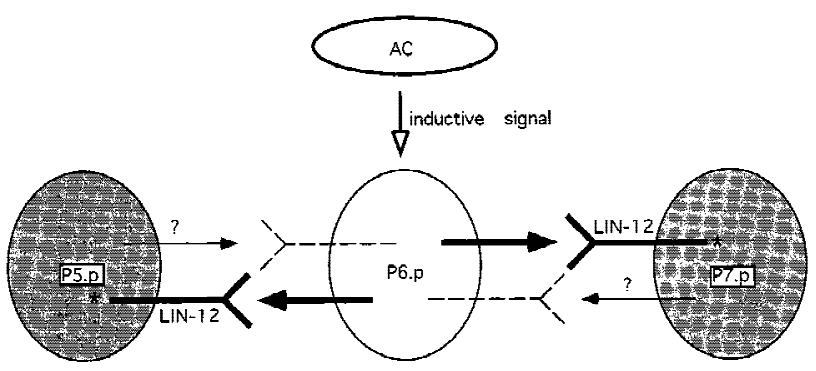

Figure 5. The AC produces a ligand (open arrow), which activates a Ras-mediated signal transduction pathway in P6.p. This biases lateral signaling, so that only P5.p and P7.p attain a threshold value of activated LIN-12 (gray shading). This bias may be achieved by up-regulation of expression or activity of a ligand for LIN-12 as well as by down-regulation of LIN-12 in P6.p. been implicated in axon extension in defined neurons (Giniger et al. 1993). Recently, Giniger (1998) has shown that axon aberrations associated with reduced Notch activity do not appear to reflect underlying changes in cell identity. He also showed that $\mathrm{N}$ otch is expressed in growth cones in primary Drosophila neurons cultured in vitro (Giniger 1998). LIN-12/N otch proteins are also found in mature neurons in Drosophila (Fehon et al. 1991) and C. elegans (D. Levitan and I. Greenwald, unpubl.), raising the possibility of other functions in neural development.

Another proposed role for $\mathrm{N}$ otch is to sequester $\mathrm{Di}$ shevelled, a protein that functions in the Wingless/Wnt signal transduction pathway (Axelrod et al. 1996). In Drosophila, the Wingless (Wnt) and Notch signaling pathways both have input into many of the same cell fate decisions (e.g., Couso and Martinez Arias 1994; Gonzalez-Gaitan and Jaeckle 1995; Rulifson and Blair 1995). The dishevelled gene di splays genetic interactions with Notch as well as with wingless. Because there is some evidence that Dishevelled may interact with the intracellular domain of $\mathrm{N}$ otch, it has been proposed that $\mathrm{N}$ otch functions to sequester Dishevelled; this role for $\mathrm{N}$ otch is therefore different from that proposed for $\mathrm{N}$ otch signal transduction in cell fate decisions (see be low).

\section{The mechanism of LIN-12/Notch signal transduction}

It is now generally accepted that LIN $-12 / \mathrm{N}$ otch proteins function as receptors that are activated by the binding of DSL ligands. Genetic studies have suggested that receptor self-association may be involved in receptor activation (Greenwald and Seydoux 1990; Heitzler and Simpson 1993).

The mechanism by which activated LIN-12/N otch proteins transduce signals and alter gene expression has been unresolved. Recent results (Schroeter et al. 1998; Struhl and A dachi 1998) support an unusual mechanism for signal transduction described below.

Three important observations are pertinent to models for the mechanism of signal transduction: (1) Expression of just the intracellular domain of LIN - 12 and N otch causes phenotypes associated with LIN-12/N otch activation (Lieber et al. 1993; Struhl et al. 1993); (2) the free Notch intracellular domain is nuclearly localized (Fortini et al. 1993; Lieber et al. 1993; Struhl et al. 1993; Kopan et al. 1994; $N$ ye et al. 1994); (3) the intracellular domains of LIN-12/Notch proteins physically interact with proteins that function in the nucleus to regulate gene expression. The best characterized of these proteins are the site-specific DN A-binding protein $\mathrm{Su}(\mathrm{H})$ in Drosophila, LAG-1 in C. elegans, and CBF1 (or RBPJк) in vertebrates. Genetic studies in Drosophila and $C$. elegans have established that $\mathrm{Su}(\mathrm{H}) / \mathrm{LAG}-1$ is involved in LIN-12/N otch-mediated reception of intercellular signals (see Schweisguth and Posakony 1994; Bailey and Posakony 1995; Lecourtois and Schweisguth 1995; Christensen et al . 1996). There is also evidence that LIN 12 interacts physically and functionally with EMB-5, a 
C. elegans protein that is similar in sequence to a yeast protein that control s chromatin structure (Hubbard et al . 1996).

Three classes of signal transduction mechanisms have been proposed. One model is that LIN-12/N otch proteins act as a passive tether to keep LAG-1/Su(H) out of the nucleus and that ligand binding induces release and nuclear import of these factors (Fortini and ArtavanisTsakonas 1994). This model accounts for the physical interaction between $\mathrm{N}$ otch and $\mathrm{Su}(\mathrm{H})$ as well as evidence that $\mathrm{N}$ otch can sequester $\mathrm{Su}(\mathrm{H})$ at the membrane under some conditions (Fortini and Artavanis-T sakonas 1994). However, the passive tether model is incompatible with the genetic data. For example, the $\mathrm{Notch}^{-}$phenotype is similar to the $\mathrm{Su}(\mathrm{H})^{-}$phenotype; however, acccording to the passive tether model, $\mathrm{Su}(\mathrm{H})$ should enter the nucleus and be active in the absence of $\mathrm{N}$ otch. Furthermore, there is evidence that the subcellular localization of $\mathrm{Su}(\mathrm{H})$ does not change upon $\mathrm{N}$ otch activation in vivo (Gho et al. 1996).

A more conventional mechanism of signal transducti on could al so be invoked. The JAK-STAT signal ing system, which involves the modification of a transcription factor by a ligand-activated receptor tyrosine kinase, is a useful anal ogy (Darnell 1997). Thus, LIN-12/N otch may interact with LAG-1/Su(H) at the cell surface; in response to ligand binding, $\mathrm{Su}(\mathrm{H})$ (or another associated factor) is modified, dissociates from the receptor, translocates to the nucleus, and regulates expression of downstream target genes. At this time, there is no evi dence for any enzymatic activity of the LIN - $12 / \mathrm{N}$ otch intracellular domain or for a physically associated protein that might provide such a modifying activity.

A different model for the mechanism of signal transduction is that ligand binding leads to cleavage and nuclear transl ocation of the LIN-12/N otch intracel lular domain in a complex with transcription factors (Fig. 6). This model was first proposed to account for the observation that the intracellular domain of $\mathrm{N}$ otch is nuclearly localized and behaves like an activated receptor ( $\mathrm{Li}$ eber et al. 1993; Struhl et al. 1993). It is consistent with the findings that the intracellular domains of LIN-12/ $\mathrm{N}$ otch interact with transcription factors and studies in cultured cells suggesting that the $\mathrm{N}$ otch intracellular domain potentiates the transcriptional activation of target genes by $\mathrm{Su}(\mathrm{H}) / \mathrm{CBF} 1$ (Jarriault et al. 1995; Chen et al. 1997; Eastman et al. 1997). However, under normal in vivo circumstances, the intracellular domain has not been visualized by antibody staining in the nuclei of cells undergoing LIN -12/N otch-medi ated signaling.

Recent work in Drosophila has provided evidence in support of ligand-dependent nucl ear access and a role for the intracellular domain in regulating transcription of target genes in vivo. Struhl and Adachi (1998) reasoned that if the mechanism of $\mathrm{N}$ otch signal transduction depends on nuclear import of the intracellular domain, the amount of the intracellular domain that accumulates in the nucleus must be very low (or el se it would be visible using conventional methods). They therefore devised a sensitive assay for nuclear access by inserting a GAL4-

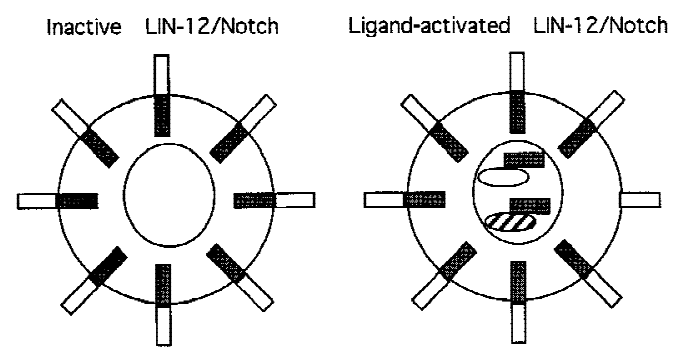

Figure 6. The ligand-dependent cleavage model for LIN-12/ $\mathrm{N}$ otch signal transduction. LIN-12/N otch proteins are expressed on the cell surface, where they are free to interact with ligands on the surface of neighboring cells. Binding of ligand causes rel ease of the intracellular domain, which translocates to the nucleus, where facilitates transcriptional activation by DNA-binding proteins such as LAG-1/Su(H)/CBF1. Other specific proteins may also be present in the transcription complex; different complexes may be involved in different decisions.

VP16 transcription factor domain into the intracellular domain of $\mathrm{N}$ otch and used this method to demonstrate ligand-dependent nuclear access as assayed by both U AS-lacZ reporter gene output and phenotypic rescue. Furthermore, they showed that nuclear access is important for signal transduction by manipulating the subcelIular localization of the intracellular domain with sequences that target to the membrane (eliminating activity) or nucleus (potentiating activity). Finally, they showed that the intracellular domain appears to participate in a transcription complex because adding a transcriptional activator domain to the intracellular domain of the full-length receptor promotes Notch activity, whereas adding transcriptional repressor domains blocks Notch activity.

The results of Struhl and A dachi (1998) provide strong evidence for in vivo nuclear access and action of the intracellular domain of $\mathrm{N}$ otch. In principle, nuclear access could be afforded by ligand-dependent cleavage and release of the intracellular domain, analogous to the events that release sterol regulatory element binding proteins (SREBPs) from a transmembrane protein in response to cholesterol depletion (for review, see Brown and Goldstein 1997). Alternatively, an unprecedented trafficking event might enable the intracellular domain of activated Notch to gain access to the nucleus while still attached to the remainder of the protein. Recent work using mammalian tissue culture cells has provided biochemical evidence for a ligand-dependent cleavage event that releases the $\mathrm{N}$ otch intracellular domain to function in the nucleus (Schroeter et al . 1998). The cleavage model presented in Figure 6 is a synthesis of the available functional and biochemical data.

\section{Other influences on LIN-12/Notch activity}

Genetic analysis in C. elegans and Drosophila has identified many genes that influence LIN-12/N otch activity. Some of these genes have been defined by mutations that result in phenotypes associated with defects in LIN -12/ 
$\mathrm{N}$ otch signal ing. Other genes have been defined by mutations that suppress or enhance mutations in the LIN $12 / \mathrm{N}$ otch signaling pathway. Some genes have been defined by both approaches.

$M$ any Drosophila genes that influence Notch activity have been characterized. Several encode nuclear proteins that may be involved in signal transduction, including mastermind (Smoller et al. 1990), neuralized (Boulianne et al. 1991), groucho (see Paroush et al . 1994; Fisher et al. 1996), and strawberry notch (M ajumdar et al . 1997). The big brain gene encodes a protein that resembles an ion channel and potentiates Notch activity (Doherty et al. 1997), and deltex encodes a cytopl asmic protein that interacts with the intracellular domain of $\mathrm{N}$ otch ( $\mathrm{M}$ atsuno et al. 1995). The scabrous gene encodes a secreted glycoprotein that influences $\mathrm{N}$ otch activity during eye development (Baker and Zitron 1995; Lee et al. 1996).

As described above, $\mathrm{Su}(\mathrm{H})$ is a transcription factor and a key signal transducing element in many cell fate decisions. Hai rless influences $\mathrm{N}$ otch signaling by negatively regulating the activity of the $\mathrm{Su}(\mathrm{H})$ (Schweisguth and Posakony 1994; Bang and Posakony 1995). Hairless interacts with $\mathrm{Su}(\mathrm{H})$ via a direct protein-protein interaction and interferes with the DNA-binding activity of $\mathrm{Su}(\mathrm{H})$ (Brou et al . 1994). The bHLH proteins of the $E(\mathrm{Spl})$ complex appear to be direct targets of $\mathrm{Su}(\mathrm{H})$ (Bailey and Posakony 1995; Lecourtois and Schweisguth 1995).

In some cases, the results of genetic and molecular characterization suggest other factors that influence cell fate decisions mediated by LIN $-12 / \mathrm{N}$ otch signaling. Here, potential effects of protein turnover are considered, as suggested by studies of the $C$. el egans sel- 1 and sel-10 genes. Also considered are aspects of protein processing and trafficking, based on studies of the Drosophila kuzbanian (kuz) gene and its C. el egans homolog, sup-17, and by studies of the C. el egans sel-12 and hop-1 presenilin genes.

\section{Protein turnover}

Studies of the C. elegans sel-1 and sel-10 genes, both negative regulators of lin-12 activity, have suggested that protein turnover may be important in LIN -12/N otch mediated cell fate decisions (Grant and Greenwald 1996, 1997; Hubbard et al. 1997). SEL-1 is similar to the Saccharomyces cerevisiae HRD 3 protein, which has been implicated in turnover of the membrane protein HMG CoA reductase (Hampton et al. 1996). SEL-10 is a member of the F-box/WD 40 repeat-containing protein family, members of which have been shown to target proteins for ubiquitination and turnover (for review, see Hoyt 1997).

Constitutive turnover or ligand-induced down-regulation of LIN -12/N otch proteins may be important for cell fate decisions to occur normally (discussed in Grant and Greenwald 1997; Hubbard et al. 1997). For example, in the AC/VU decision, Z1.ppp and Z4.aaa initial ly signal each other: in the absence of turnover or down-regulation of LIN-12, this initial signaling might create sufficient activated receptor so that both cells would achieve the threshold value of effector activity; in effect, rapid turnover would limit the output from a single ligandreceptor interaction. Furthermore, in this decision, signaling from activated receptor would persist in the absence of down-regulation, masking the effects of the differential transcription underlying the feedback mechanism. Receptor turnover may al so be necessary in cases where $\mathrm{N}$ otch is used for successive decisions, such as in the specification of fates during Drosophila eye development (Cagan and Ready 1989), so that activated receptors are cleared before the next signaling event occurs.

\section{Protein processing and trafficking}

LIN -12/N otch proteins (and their ligands) are transmembrane proteins that must be properly processed, modified, and sorted. LIN -12/N otch proteins appear to be proteolytically cleaved in the extracellular domain to yield a heterodimer composed of the amino- and carboxy-terminal cleavage products (Crittenden et al. 1994; Blaumueller et al. 1997; Pan and Rubin 1997). This proteolytic cleavage event is proposed to occur in intracellular vesicles and to be important for $\mathrm{N}$ otch trafficking to the cell surface (Blaumueller et al. 1997).

Several genes that influence LIN-12/Notch activity appear to influence processing and trafficking. With the exception of the putative ligand-induced cleavage event, it is not known whether various steps in LIN $-12 / \mathrm{N}$ otch processing and trafficking occur constitutively or are points of regulation during cell fate decisions.

A metalloprotease of the ADAM family-Kuz in Drosophila and SUP-17 in C. elegans-facilitates lin-12/ Notch signaling (Rooke et al. 1996; Pan and Rubin 1997; Sotillos et al. 1997; Tax et al. 1997; Wen et al. 1997). The genetic interaction between sup-17/kuz and lin-12/ Notch requires the LIN $-12 / \mathrm{N}$ otch extracellular domain (Pan and Rubin 1997; Sotillos et al. 1997; Wen et al. 1997). Pan and Rubin (1997) have presented evidence that Kuz is required in Drosophila for the proteolytic processing of $\mathrm{N}$ otch into two fragments consistent with a cleavage event in the extracellular domain. It is not known whether the LIN -12/N otch extracel lular domain is a substrate of the SUP-17/Kuz protease or whether SUP-17/Kuz is involved in maturation or activation of LIN $-12 / \mathrm{N}$ otch proteins.

Proteins of the presenilin family have also been identified as influences on LIN-12/Notch signaling. In humans, presenilins were identified by mutations that cause Alzheimer's disease (for review, see Schellenberg 1995). A connection between presenilin activity and LIN $-12 / \mathrm{N}$ otch signal ing was first suggested by the finding that the $C$. elegans sel-12 presenilin facilitates the activity of lin-12 and glp-1 (Levitan and Greenwald 1995), and supported by the observation that reducing the activity of both $\mathrm{C}$. el egans presenilins causes phenotypes associated with the absence of lin-12 and glp- 1 activity (Li and Greenwald 1997). The functional relationship between presenilin and $\mathrm{N}$ otch activity appears to have been evolutionarily conserved, because targeted 
disruption of the mouse PS1 gene causes striking phenotypes associated with reduced $\mathrm{N}$ otch activity (Shen et al . 1997; Wong et al. 1997).

Presenilins are multipass transmembrane proteins, and their mechanism of function is not known. A recent study has suggested that PS1 is required for a cleavage event during amyloid precursor protein processing (DeStrooper et al. 1998), although whether presenilins promote cleavage per se or a trafficking event necessary for cleavage is not known. The effect of presenilins on amyloid precursor protein processing is intriguing in view of the proteolytic processing events that LIN-12/N otch proteins undergo. Perhaps presenilins facilitate LIN -12/ $\mathrm{N}$ otch activity by promoting one or more proteolysis events associated with LIN-12/N otch maturation or activation.

\section{Conservation of LIN-12/Notch form and function in vertebrates}

There is every reason to believe that precedents established from studies in invertebrates will be directly applicable to vertebrates. Many of the components that have been identified in invertebrates, principally by genetic methods, have also been found in vertebrates (see Table 1). Furthermore, the available functional and expression data indicate that the vertebrate $\mathrm{N}$ otch pathway plays similar roles in mediating cell-cell interactions that specify cell fate (for review, see Gridley 1997). For example, activity of the Xenopus ligand X-Delta- 1 appears to control lateral specification of neurons, as ectopic X-Delta-1 activity inhibits the formation of primary neurons, and a dominant-negative form of X-Delta-1 promotes the formation of excess primary neurons (Chitnis et al. 1995). It is likely that further identification of components of the signal transduction mechanism and of other influences on LIN-12/N otch signaling in invertebrates will continue to inform studies of $\mathrm{N}$ otch signaling in vertebrate development.

\section{Acknowledgments}

I thank Gary Struhl, Gerald Siu, and members of my laboratory for comments on this manuscript. I am an Associate Investigator of the Howard Hughes M edical Institute.

\section{References}

Axelrod, J.D., K. Matsuno, S. Artavanis-Tsakonas, and N. Perrimon. 1996. Interaction between Wingless and $\mathrm{N}$ otch signaling pathways mediated by dishevelled. Science 271: 1826-1832.

Bailey, A.M. and J.W. Posakony. 1995. Suppressor of Hairless directly activates transcription of Enhancer of split complex genes in response to N otch receptor activity. Genes \& Dev. 9: $2609-2622$.

Baker, N .E. and A.E. Zitron. 1995. Drosophila eye devel opment: $\mathrm{N}$ otch and Delta amplify a neurogenic pattern conferred on the morphogenetic furrow by scabrous. Mech. Dev. 49: 173189.

Bang, A.G. and J.W. Posakony. 1995. Hairless promotes stable commitment to the sensory organ precursor cell fate by negatively regulating the activity of the Notch signaling pathway. Dev. Biol. 172: 479-494.

Blaumueller, C.M., H. Qui, P. Zagouras, and S. Artavanis-Tsakonas. 1997. Intracellular cleavage of $\mathrm{N}$ otch leads to a heterodimeric receptor on the plasma membrane. Cell 90: 281291.

Boulianne, G.L., A. de la Concha, J.A. Campos-Ortega, L.Y. Jan, and Y.N . Jan. 1991. The Drosophila neurogenic gene neuralized encodes a novel protein and is expressed in precursors of larval and adult neurons. EMBO J. 10: 2975-2983.

Brou, C., F. Logeat, M. Lecourtois, J. Vendekerckhove, P. Kourilsky, F. Schweisguth, and A. Israel. 1994. Inhibition of the DN A-binding activity of Drosophila Suppressor of Hairless and of its human homolog, KBF2/RBP-Jк, by direct proteinprotein interaction with Drosophila Hairless. Genes \& Dev. 8: 2491-2503.

Brown, M.S. and J.L. Goldstein. 1997. The SREBP pathway: regulation of cholesterol metabolism by proteolysis of a membrane-bound transcription factor. Cell 89: 331-340.

Cagan, R.L. and D.F. Ready. 1989. N otch is required for successive cell decisions in the developing Drosophila retina. Genes \& Dev. 3: 1099-1112.

Chen, Y., W.H. Fischer, and G.N. Gill. 1997. Regulation of the ERBB-2 promoter by RBPJ $\kappa$ and NOTCH. J. Biol. Chem. 272: 14110-14114.

Chitnis, A., D. Henrique, J. Lewis, D. Ish-Horowicz, and C. Kinter. 1995. Primary neurogenesis in Xenopus embryos regulated by a homol ogue of the Drosophila neurogenic gene Delta. Nature 375: 736-737.

Christensen, S., V. Kodoyianni, M. Bosenberg, L. Friedman, and J. Kimble. 1996. lag-1, a gene required for lin-12 and glp-1 signaling in $\mathrm{C}$. el egans, is homologous to human CBF1 and Drosophila Su(H). Development 122: 1373-1383.

Couso, J.P. and A. Martinez Arias. 1994. N otch is required for wingless signaling in the epidermis of Drosophila. Cell 79: 259-272.

Crittenden, S.E., E. Troemel, T.C. Evans, and J. Kimble. 1994. GLP-1 is localized to the mitotic region of the C. elegans germline. Development 120: 2901-2911.

Cubas, P., J.F. de Celis, S. Campuzano, and J. Modolell. 1991. Proneural clusters of achaete-scute expression and the generation of sensory organs in the Drosophila imaginal wing disc. Genes \& Dev. 5: 996-1008.

Darnell, J.E. 1997. STATS and gene regulation. Science 277: 1630-1635.

DeCelis, J.F., A. Garcia-Bellido, and S.J. Bray. 1996. Activation and function of Notch at the dorsal-ventral boundary of the wing imaginal disc. Development 122: 359-369.

DeStrooper, B., P. Saftig, K. Craessaerts, H. Vanderstichele, G. Guhde, W. Annaert, K. Von Figura, and F. Van Leuven. 1998. Deficiency of presenilin-1 inhibits the normal cleavage of amyloid precursor protein. Nature 391: 387-380.

Diaz-Benjumea, F.J. and S.M. Cohen. 1995. Serrate signals through $\mathrm{N}$ otch to establish a Wingless-dependent organizer at the dorso-ventral compartment boundary of the Drosophila wing. Development 121: 4215-4225.

Doherty, D., G. Feger, S. Younger-Shepherd, L.Y. Jan, and Y.N. Jan. 1996. Delta is a ventral to dorsal signal complementary to Serrate, another N otch ligand, in Drosophila wing formation. Genes \& Dev. 10: 421-434.

Doherty, D., L.Y. Jan, and Y.N. Jan. 1997. The Drosophila neurogenic gene big brain, which encodes a membrane-associated protein, acts cell autonomously and can act synergistically with Notch and Delta. Development 124: 3881-3893.

Eastman, D.S., R. Slee, E. Skoufos, L. Bangal ore, S. Bray, and C. 
Delidakis. 1997. Synergy between Suppressor of Hairless and $\mathrm{N}$ otch in regulation of Enhancer of split $\mathrm{m} \gamma$ and $\mathrm{m} \delta$ expression. Mol. Cell. Biol. 17: 5620-5628.

Fehon, R.G., K. Johansen, I. Rebay, and S. Artavanis-T sakonas. 1991. Complex cellular and subcellular regulation of $\mathrm{N}$ otch expression during embryonic and imaginal development of Drosophila: implications for Notch function. J. Cell Biol. 113: 657-669.

Fisher, A.L., S. Ohsako, and M. Caudy. 1996. The WRPW motif of the hairy-related basic helix-loop-helix repressor proteins acts as a 4 amino acid transcription repression and proteinprotein interaction domain. Mol. Cell. Biol. 16: 2670-2677.

Fleming, R.J., Y. Gu, and N.A. Hukriede. 1997. Serrate-mediated activation of Notch is specifically blocked by the product of the gene fringe in the dorsal compartment of the Drosophila wing imaginal disc. Development 124: 2973-2981.

Fortini, M.E. and S. Artavanis-T sakonas. 1994. The suppressor of hairless protein participates in $\mathrm{N}$ otch receptor signaling. Cell 79: 273-282.

Fortini, M.E., I. Rebay, L.A. Caron, and S. Artavanis-Tsakonas. 1993. An activated N otch receptor blocks cell fate commitment in the developing Drosophila eye. Nature 365: 555557.

Gho, M., M. Lecourtois, G. Geraud, J.W. Posakony, and F. Schweisguth. 1996. Subcellular localization of Suppressor of Hairless in Drosophila sense organ cells during N otch signalling. Development 122: 1673-1682.

Giniger, E. 1998. A role for Abl in NOTCH signaling. Neuron 20: 667-681.

Giniger, E., L.Y. Jan, and Y.N. Jan. 1993. Specifying the path of the intersegmental nerve of the Drosophila embryo: a role for Delta and Notch. Development 117: 431-440.

Gonzal ez-Gaitan, M. and H. Jaeckle. 1995. Invagination centers within the Drosophila somatogastric nervous system anlage are positioned by Notch-mediated signaling which is spatially controlled through wingless. Development 121: 23132325.

Grant, B. and I. Greenwald. 1996. The Caenorhabditis el egans sel-1 gene, a negative regulator of I in-12 and gl p-1, encodes a predicted extracellular protein. Genetics 143: 237-247.

- - - 1997. Structure, function and expression of SEL-1, a negative regulator of LIN-12 and GLP-1 in C. elegans. De velopment 124: 637-644.

Greenwald, I. 1997. Development of the vulva. In Caenorhabditis el egans II (ed. D.L. Riddle, T. Blumenthal, B.J. M eyer, and J.R. Priess). Cold Spring Harbor Laboratory Press, Cold Spring Harbor, NY.

Greenwald, I., and G. Seydoux. 1990. Analysis of gain-of-function mutations of the lin-12 gene of Caenorhabditis el egans. Nature 346: 197-199.

Greenwald, I.S., P.W. Sternberg, and H.R. Horvitz. 1983. The lin-12 locus specifies cell fates in Caenorhabditis elegans. Cell 34: 435-444.

Gridley, T. 1997. N otch signaling in vertebrate development and disease. Mol. Cell. Neurosci. 9: 103-108.

Guo, M., L.Y. Jan, and Y.N. Jan. 1996. Control of daughter cell fates during asymmetric division: interaction of $\mathrm{Numb}$ and N otch. Neuron 17: 27-41.

Hampton, R., R. Gardner, and J. Rine. 1996. Role of 265 proteasome and HRD genes in the degradation of 3-hydroxyl-3methylglutaryl-CoA reductase, an integral endoplasmic reticulum membrane protein. Mol. Biol. Cell 7: 2029-2044.

Hartenstein, V. and J.W. Posakony. 1989. Development of adult sensilla on the wing and notum of Drosophila melanogaster. Development 107: 389-405.

- - 1990. A dual function of the Notch gene in Drosophila sensillum development. Dev. Biol. 142: 13-30.

Heitzler, P. and P. Simpson. 1991. The choice of cell fate in the epidermis of Drosophila. Cell 64: 1083-1092.

_-_. 1993. Altered epidermal growth factor-like sequences provide evidence for a role of Notch as a receptor in cell fate decisions. Development 117: 1113-1123.

Henderson, S.T., D. Gao, E.J. Lambie, and J. Kimble. 1994. Iag-2 may encode a signaling ligand for the GLP-1 and LIN-12 receptors of C. elegans. Development 120: 2913-2924.

Heitzler, P., M. Bourouis, L. Ruel, C. Carteret, and P. Simpson. 1996. Genes of the Enhancer of split and achaete-scute complexes are required for a regulatory loop between $\mathrm{N}$ otch and Delta during lateral signalling in Drosophila. Development 122: 161-171.

Hoyt, M.A. 1997. Eliminating all obstacles: Regulated proteolysis in the eukaryotic cell cycle. Cell 91: 149-152.

Hubbard, E.J.A., Q. Dong, and I. Greenwald. 1996. Evidence for physical and function association between EMB-5 and LIN 12 in Caenorhabditis el egans. Science 273: 112-115.

Hubbard, E.J.A., G. Wu, J.K. Kitajewski, and I. Greenwal d. 1997. sel-10, a negative regulator of Iin-12 activity in Caenorhabditis el egans, encodes a member of the CDC 4 family of proteins. Genes \& Dev. 11: 3182-3193.

Huppert, S.S., T.L. Jacobsen, and M.A.T. Muskavitch. 1997. Feedback regulation is central to Delta-N otch signalling required for Drosophila wing vein morphogenesis. Development 124: 3283-3291.

Irvine, K.D. and T. Vogt. 1997. Dorsal-ventral signaling in limb development. Curr. Opin. Cell Biol. 9: 867-876.

Irvine, K.D. and E. Wieschaus. 1994. fringe, a boundary-specific signaling molecule, mediates interactions between dorsal and ventral cells during Drosophila wing development. Cell 79: 595-606.

Jan, Y.N . and L.Y. Jan. 1995. Maggot's hair and bug's eye: Role of cell interactions and intrinsic factors in cell fate specification. Neuron 14: 1-5.

Jarriault, S., S. Brou, F. Logeat, E.H. Schroeter, R. Kopan, and A. Israel. 1995. Signalling downstream of activated mammalian N otch. Nature 377: 355-358.

Johnston, S.H., C. Rauskolb, R. Wilson, B. Prabhakaran, K.D. Irvine, and T.F. Vogt. 1997. A family of mammalian Fringe genes implicated in boundary determination and the $\mathrm{N}$ otch pathway. Development 124: 2245-2254.

Katz, W.S., R.J. Hill, T.R. Clandinin, and P.W. Sternberg. 1995. Different levels of the $C$. elegans growth factor LIN-3 promote distinct vulval precursor fates. Cell 82: 297-307.

Kim, J., K.D. Irvine, and S.B. Carroll. 1995. Cell interactions and inductive signals at the dorsal/ventral boundary of the developing Drosophila wing. Cell 82: 795-802.

Kimble, J. 1981. Alteration in cell lineage following laser ablation of cells in the somatic gonad of Caenorhabditis el egans. Dev. Biol. 87: 286-300.

Kimble, J. and D. Hirsh. 1979. The post-embryonic cell lineages of the hermaphrodites and male gonads in Caenorhabditis elegans. Dev. Biol. 87: 396-417.

Knoblich, J.A., L.Y. Jan, and Y.N. Jan. 1995. Asymmetric segregation of $\mathrm{Numb}$ and Prospero during cell division. Nature 377: 624-627.

Koga, M. and Y. Ohshima. 1995. M osaic analysis of the let-23 gene function in vulval induction of Caenorhabditis elegans. Devel opment 121: 2655-2666.

Kopan, R., J.S. N ye, and H. Weintraub. 1994. The intracellular domain of mouse $\mathrm{N}$ otch: a constitutively activated repressor of myogenesis at the basic helix-loop-helix region of $M$ yoD. Development 120: 2385-2396.

Kornfeld, K. 1997. Vulval development in Caenorhabditis el- 
egans. Trends Genet. 13: 55-61.

Kunisch, M., M. Haenlin, and J.A. Campos-Ortega. 1994. Lateral inhibition mediated by the Drosophila neurogenic gene Delta is enhanced by proneural proteins. Proc. Natl. Acad. Sci. 91: 10139-10143.

Lambie, E. and J. Kimble. 1991. Two homologous genes, lin-12 and glp-1, have overlapping functions. Development 112: 231-240.

Lawrence, P. 1992. The making of a fly. Blackwell Scientific Publications, Oxford, UK.

Lawrence, P. and G. Struhl. 1996. M orphogens, compartments, and pattern: Lessons from Drosophila? Cell 85: 951-961.

Lecourtois, M. and F. Schweisguth. 1995. The neurogenic Suppressor of Hairless DN A-binding protein mediates the transcriptional activation of the Enhancer of split complex genes triggered by N otch signaling. Genes \& Dev. 9: 2598-2608.

Lee, E.C., X. Xu, S.Y. Yu, and N.E. Baker. 1996. The scabrous gene encodes a secreted glycoprotein dimer and regulates proneural development in Drosophila eyes. Mol. Cell Biol. 16: $1179-1188$.

Levitan, D. and I. Greenwald. 1995. Facilitation of Iin-12-mediated signalling by sel-12, a Caenorhabditis el egans S182 Alzheimer's disease gene. Nature 377: 351-354.

$\mathrm{Li}, \mathrm{X}$. and I. Greenwald. 1997. HOP-1, a Caenorhabditis el egans presenilin, appears to be functionally redundant with SEL-12 presenilin and to facilitate LIN - 12 and GLP-1 signaling. Proc. Natl. Acad. Sci. 94: 12204-12209.

Lieber, T., S. Kidd, E. Alcamo, V. Corbin, and M.W. Young. 1993. Antineurogenic phenotypes induced by truncated Notch proteins indicate a role in signal transduction and may point to a novel function for Notch in nuclei. Genes \& Dev. 7: 1949-1965.

Majumdar, A., R. Nagaraj, and U. Banerjee. 1997. strawberry notch encodes a conserved nuclear protein that functions downstream of $\mathrm{N}$ otch and regulates gene expression along the developing wing margin of Drosophila. Genes \& Dev. 11: 1341-1353.

M ango, S.E., C.J. Thorpe, P.R. M artin, S.H. Chamberlain, and B. Bowerman. 1994. Two maternal genes, apx-1 and pie-1, are required to distinguish the fates of equival ent blastomeres in the early Caenorhabditis elegans embryo. Development 120: 2305-2315.

Matsuno, K., R.J. Diederich, M.J. Go, C.M. Blaumueller, and S. Artavanis-Tsakonas. 1995. Deltex acts as a positive regulator of $\mathrm{N}$ otch signaling through interactions with the $\mathrm{N}$ otch ankyrin repeats. Development 121: 2633-2644.

Mello, C.C., B.W. Draper, and J.R. Priess. 1994. The maternal genes apx-1 and glp-1 and establishment of dorsal-ventral polarity in the early C. elegans embryo. Cell 77: 95-106.

Micchelli, C.A., E.J. Rulifson, and S.S. Blair. 1997. The function and regulation of cut expression on the wing margin of Drosophila: N otch, Wingless and a dominant negative role for Delta and Serrate. Development 124: 1485-1495.

Mickey, K.M., C.C. M ello, M.K. Montgomery, A. Fire, and J.R. Priess. 1996. An inductive interaction in 4-cell stage C. elegans embryos involves APX-1 expression in the signalling cell. Development 122: 1791-1798.

Nye, J.S., R. Kopan, and R. Axel. 1994. An activated Notch suppresses neurogenesis and myogenesis but not gl iogenesis in mammalian cells. Development 120: 2385-2396.

Oellers, N., M. Dehio, and E. Knust. 1994. bHLH proteins encoded by the Enhancer of split complex of Drosophila negatively interfere with transcriptional activation mediated by proneural genes. Mol. \& Gen. Genet. 244: 465-473.

Pan, D. and G.M. Rubin. 1997. Kuzbanian controls proteolytic processing of $\mathrm{N}$ otch and mediates lateral inhibition during
Drosophila and vertebrate neurogenesis. Cell 90: 271-280.

Panin, V.M., V. Papayannopoulos, R. Wilson, and K.D. Irvine. 1997. Fringe modulates $\mathrm{N}$ otch-ligand interactions. Nature 387: 908-910.

Parks, A.L. and M.A.T. Muskavitch. 1993. Delta function is required for bristle organi determination and morphogenesis in Drosophila. Dev. Biol. 157: 484-496.

Parks, A.L., S.S. Huppert, and M .A. Muskavitch. 1997. The dynamics of neurogenic signalling underlying bristle development in Drosophila melanogaster. Mech. Dev. 63: 61-74.

Paroush, Z., R.L. Finley, T. Kidd, S.M. Wainwright, P.L. Ingham, R. Brent, and D. Ish-Horowicz. 1994. Groucho is required for Drosophila neurogenesis, segmentation, and sex determination and interacts directly with Hairy-related bHLH proteins. Cell 79: 805-815.

Rhyu, M.S., L.Y. Jan, and Y.N. Jan. 1994. Asymmetric distribution of Numb protein during division of the sensory organ precursor cell confers distinct fates to daughter cells. Cell 76: 477-491.

Rooke, J., D. Pan, T. Xu, and G.M. Rubin. 1996. KUZ, a conserved metalloprotease-disintegrin protein with two roles in Drosophila neurogenesis. Science 273: 1227-1231.

Rulifson, E.J. and S.S. Blair. 1995. N otch regulates wingless expression and is not required for reception of the paracrine wingless signal during wing margin neurogenesis in Drosophila. Development 121: 2813-2824.

Schellenberg, G.D. 1995. Genetic dissection of Alzheimer disease, a heterogeneous disorder. Proc. Natl. Acad. Sci. 92: 8552-8559.

Schroeter, E.H., J.A. Kisslinger, and R. Kopan. 1998. Notch1 signaling requires ligand-induced proteolytic release of the intracellular domain. Nature (in press).

Schweisguth, F. 1995. Suppressor of Hairless is required for signal reception during lateral inhibition in the Drosophila pupal notum. Development 121: 1875-1884.

Schweisguth, F. and J.W. Posakony. 1994. Antagonistic activities of Suppressor of Hairless and Hairless control al tnerative cell fates in the Drosophila adult epidermis. Development 120: 1433-1441.

Seydoux, G. and I. Greenwald. 1989. Cell autonomy of Iin-12 function in a cell fate decision in C. elegans. Cell 57: 12371245.

Shawber, C., D. N ofziger, J.J. Hsieh, C. Lindsell, O. Bogler, D. Hayward, and G. Weinmaster. 1996. N otch signaling inhibits muscle cell differentiation through a CBF1-independent pathway. Development 122: 3765-3773.

Shellenbarger, D. and J. Mohler. 1978. Temperature-sensitive periods and autonomy of pleiotropic effects of I(1)Ntsl, a conditional Notch lethal in Drosophila. Dev. Biol. 62: 432446.

Shen, J., R.T. Bronson, D.F. Chen, W. Xia, D.J. Selkoe, and S. Tonegawa. 1997. Skeletal and CNS defects in Presenilin-1 deficient mice. Cell 89: 629-639.

Simske, J.S. and S.K. Kim. 1995. Sequential signalling during Caenorhabditis el egans vulval induction. Nature 375: 142146.

Simpson, P. 1990. Lateral inhibition and the devel opment of the sensory bristles of the adult peripheral nervous system of Drosophila. Development 109: 509-519.

Skeath, J.B. and S.B. Carroll. 1994. The achaete-scute complex: Generation of cellular pattern and fate within the Drosophila nervous system. FASEB J. 8: 714-721.

Smoller, D., C. Friedel, A. Schmid, D. Bettler, L. Lam, and B. Yedvobnick. 1990. The Drosophila neurogenic locus mastermind encodes a nuclear protein unusually rich in amino acid homopolymers. Genes \& Dev. 4: 1688-1700. 
Sotillos, S., F. Roch, and S. Campuzano. 1997. The metalloprotease-disintegrin Kuzbanian partcipates in Notch activation during growth and patterning of Drosophila imaginal discs. Development 124: 4769-4779.

Spana, E.P. and C.Q. Doe. 1995. A collection of cortical crescents: Asymmetric protein localization in CNS precursor cells. Neuron 15: 991-995.

- - - 1996. N umb antagonizes $\mathrm{N}$ otch signaling to specify sibling neuron cell fates. Neuron 17: 21-26.

Spana, E.P., C. Kopczynski, C.S. Goodman, and C.Q. Doe. 1995. Asymmetric localization of numb autonomously determines sibling neuron identity in the Drosophila CNS. Development 121: 3489-3494.

Stern, C.D. 1954. Two or three bristles. Am. Sci. 42: 213-247.

Sternberg, P.W. 1988. Lateral inhibition during vulval induction in Caenorhabditis el egans. Nature 335: 551-554.

Sternberg, P.W. and H.R. Horvitz. 1986. Pattern formation during vulval development in C. el egans. Cell 44: 761-772.

Struhl, G. and A. Adachi. 1998. Nuclear access and action of $\mathrm{N}$ otch in vivo. Cell 93: 649-660.

Struhl, G., K. Fitzgerald, and I. Greenwald. 1993. Intrinsic activity of the Lin-12 and $\mathrm{N}$ otch intracel lular domains in vivo. Cell 74: 331-345.

Sturtevant, M.A., M. Roark, and E. Bier. 1993. The Drosophila rhomboid gene mediates the localized formation of wing veins and interacts genetically with components of the EGF-R signaling pathway. Genes \& Dev. 7: 961-973.

Sulston, J.E. and J.G. White. 1980. Regulation and cell autonomy during postembryonic development of Caenorhabditis elegans. Dev. Biol. 78: 577-597.

Tax, F.E., J.J. Y eargers, and J.H. Thomas. 1994. Sequence of C. elegans lag-2 reveals a cell-signalling domain shared with Delta and Serrate of Drosophila. Nature 368: 150-154.

Tax, F.E., J.H. Thomas, E.L. Ferguson, and H.R. Horvitz. 1997. Identification and characterization of genes that interact with lin-12 in Caenorhabditis el egans. Genetics 147: 16751695.

U emura, T., S. Shepherd, L. Ackerman, L.Y. Jan, and Y.N. Jan. 1989. numb, a gene required in determination of cell fate during sensory organ formation in Drosophila embryos. Cell 58: 349-360.

Wang, S., S. Younger-Shepherd, L.Y. Jan, and Y.N. Jan. 1997. Only a subset of the binary cell fate decisions mediated by $\mathrm{Numb} / \mathrm{N}$ otch signaling in Drosophila sensory organ lineage requires Suppressor of Hairless. Development 124: 44354446.

Weinmaster, G. 1997. The ins and outs of $\mathrm{N}$ otch signaling. Mol. Cell. Neurosci. 9: 91-102.

Wen, C., M.M. Metzstein, and I. Greenwald. 1997. SUP-17, a Caenorhabditis elegans ADAM protein related to Drosophila KUZBAN IAN, and its role in LIN -12/N otch signalling. Development 124: 4759-4767.

Wiggl esworth, V.B. 1940. Local and general factors in the development of "pattern" in Rhodnius prolixus (Hemiptera). J. Exp. Biol. 17: 180-200.

Wilkinson, H.A. and I. Greenwald. 1995. Spatial and temporal patterns of Iin-12 expression during $C$. el egans hermaphrodite development. Genetics 141: 513-526.

Wilkinson, H.A., K. Fitzgerald, and I. Greenwald. 1994. Reciprocal changes in expression of the receptor lin-12 and its ligand lag-2 prior to commitment in a C. elegans cell fate decision. Cell 79: 1187-1198.

Wolfsberg, T.G. and J.M. White. 1996. ADAMs in fertilization and development. Dev. Biol. 180: 389-401.

Wong, P.C., H. Zheng, H. Chen, M.W. Becher, D.J.S. Sirinathsinghji, M.W. Trumbauer, H.Y. Chen, D.L. Price, L.H.T. Van der Ploeg, and S.S. Sisodia. 1997. Presenilin 1 is required for Notch1 and DII1 expression in the paraxial mesoderm. Nature 387: 288-292. 


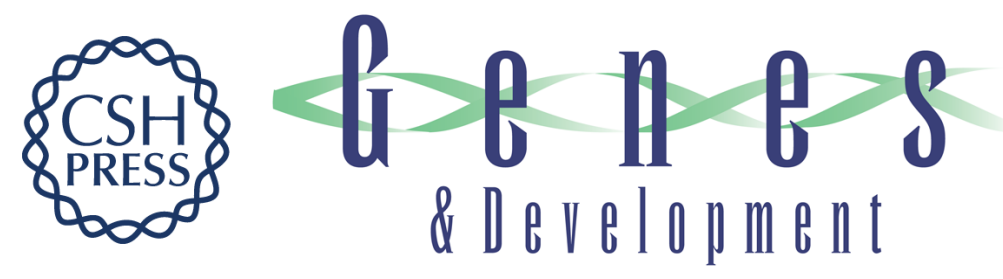

\section{LIN-12/Notch signaling: lessons from worms and flies}

Iva Greenwald

Genes Dev. 1998, 12:

Access the most recent version at doi:10.1101/gad.12.12.1751

References This article cites 116 articles, 60 of which can be accessed free at: http://genesdev.cshlp.org/content/12/12/1751.full.html\#ref-list-1

License

Email Alerting Receive free email alerts when new articles cite this article - sign up in the box at the top Service right corner of the article or click here.

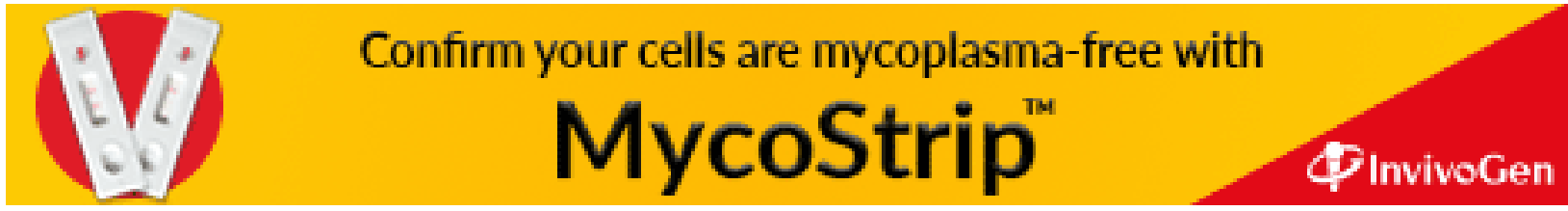

